\title{
Narmada river water quality assessment using benthic macro-invertebrates at Barwani, Rajghat Madhya Pradesh
}

\section{Khichi Yogesh}

Head, Post Graduate Department of Zoology, Umiya Girls College Rau Indore, M.P., INDIA

\begin{abstract}
River Narmada is one of the 13 prominent rivers of India, which covers 98,797 sq $\mathrm{km}$ of total water-shed area. Narmada is considered to be the lifeline of Madhya Pradesh and is one of the most important west flowing rivers of India. The monitoring of water quality of Narmada river was carried out for one year August 2011 to July 2012. Barwani sampling stations were selected at downstream of Narmada River. The water samples collected were analyzed, as per standard methods parameters such as $\mathrm{pH}$, Turbidity were measured in-situ. Raised values of physicochemical parameters indicate the pollution of riverine ecosystem due to domestic wastes, municipal sewage, industrial effluent from Security Paper Mill (SPM) and agricultural run-off that influence the water quality directly or indirectly. Statistical analysis carried out through correlation method and also evaluates Average values (AV), Standard Deviation (SD), Standard Variance (SV),Standard Error (SE) and 95\% Confidence Limit (CL) to assess the pollution load assessment. The results revealed that most of the water samples were below or out of limited; according to the WHO, BIS standards.
\end{abstract}

KEY WORDS: STATISTICAL ANALYSIS, NARMADA RIVER, WATER POLLUTION, RIVER WATER QUALITY, BARWANI, PHYSICO-CHEMICAL ANALYSIS

\section{INTRODUCTION}

Macro-invertebrates are most frequently used in biomonitoring studies because the responses of macro-invertebrates to organic and inorganic pollution have been extensively documented (Thorne and Williams., 1997; Kazanci. and Dugal., 2000). They have sensitive life stages that respond to stress and integrate effects of both shortterm and long-term environmental stressors (EPA., 1998) and they are important areas for maintaining biodiversity (Meyer et al., 2007 Richardson and Danehy 2007). The study of benthic macro-invertebrates provides a method to determine the water quality of a stream based on collection and identification of stream-bottom (benthic)

\section{ARTICLE INFORMATION:}

*Corresponding Author: Yogeshkhch@gmail.com Received $27^{\text {th }}$ Dec, 2017

Accepted after revision $17^{\text {th }}$ March, 2018

BBRC Print ISSN: 0974-6455

Online ISSN: 2321-4007 CODEN: USA BBRCBA

Thomson Reuters ISI ESC / Clarivate Analytics USA and

W. Crossref Indexed Journal

NAAS Journal Score 2017: 4.38 SJIF 2017: 4.196

- A Society of Science and Nature Publication, Bhopal India 2018. All rights reserved.

Online Contents Available at: http//www.bbrc.in/

DOI: $10.21786 / \mathrm{bbrc} / 11.1 / 22$ 
macro-invertebrates. This study has been done to find out the diversity of benthic macro-invertebrates. Benthic study in Malwa region of Madhya Pradesh is scare except that of Varshney et al., 1976, Rao et al., 1985, Sunny and Diwan., 1991 Sharma 2016, Sharma et al., 2007, Khichi et al., 2017).

\section{MATERIAL AND METHODS}

Description of Study Area The Narmada river is considered as the life line of Madhya Pradesh. The catchment area of the river exists in the States of Madhya Pradesh (86.18\%), Gujarat (11.6\%), Maharashtra (1.5\%), and Chhattisgarh (0.72\%). During its course, the river drops from an elevation of $1051 \mathrm{~m}$ to sea level, and flows through narrow gorges in the head reaches. The basin is bounded on the north by the Vindhya ranges, on the east by the Maikal range, on the south by the Satpura ranges and on the west by the Arabian Sea. Deep black soil covers the major portion of the basin. The river has 41 tributaries, of which 22 are on the left bank and 19 are on the right bank. The Barna, Tawa, Kolar, and Sukta dams have been constructed on the tributaries. The Bargi is constructed on the mainstream, while the Indirasagar, Omkareshwar, Maheshwar and Sardar Sarovar dams are under construction.

\section{SAMPLING STATIONS BARWANI}

Barwani, also known as Siddh Nagar, is an important city and a municipality in Barwani district in the state of Madhya Pradesh, India. The place is also famous for chool giri, Jain pilgrimage center of Bawangaja. The town is situated near the left bank of the Narmada river. Latitude (DMS) $22^{\circ} 10^{\prime}, 60 ” \mathrm{~N}$ and Longitude (DMS) $74^{\circ}$ 54', 0 “ E.

\section{PHYSICO CHEMICAL ANALYSIS OF WATER}

The water samples were collected from the sampling station Barwani ,for the period of 12 months from August 2011 to July 2012. In the analysis of the Physico-chemical properties of water, standard methods prescribed in limnological literature were used. Parameters like Temperature, $\mathrm{pH}$ and Turbidity were determined at the site, while other parameters like Biochemical oxygen demand, Chloride, Alkalinity, total Solids were determined in the laboratory. The Physico- Chemical parameters of water were determined as per standard methods of APHA (2005), Welch (1998), Golterman (1991).

\section{RESULTS AND DISCUSSION}

\section{WATER TEMPERATURE}

The oxidation of organic matter is highly influenced by the temperature of water. Temperature of river water depends upon the season, climatic zone, where river is flowing, time of sampling and also upon the temperature of the effluents, which are being added in the river. Temperature fluctuation during August 2011 to July 2012 was as follows.

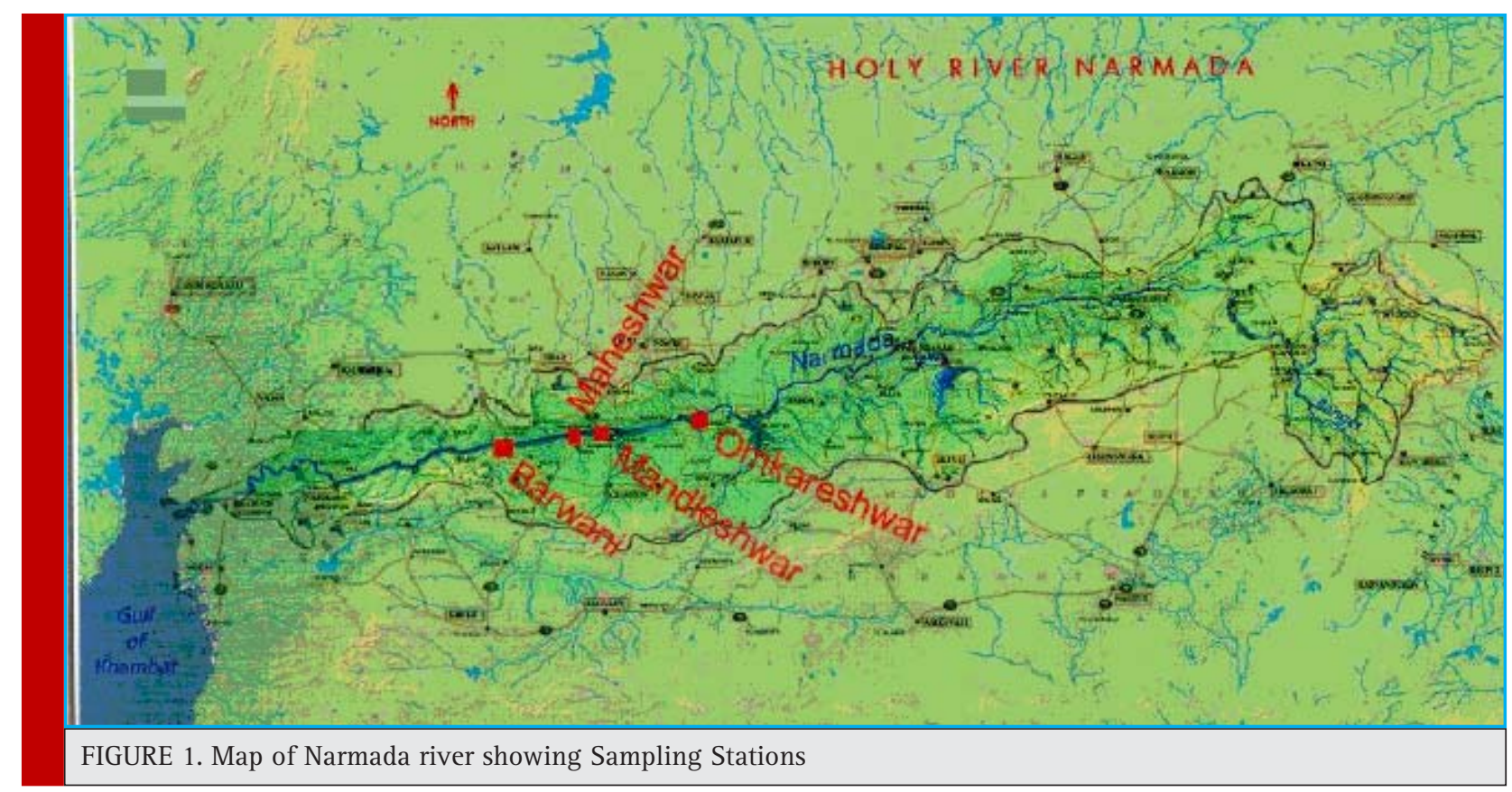

162 
Table 1. Monthly fluctuation in water temperature $\left({ }^{\circ} \mathrm{C}\right)$ of narmada river from August 2011 to July 2012 at barwani.

\begin{tabular}{|l|l|l|l|l|l|l|l|l|l|l|l|l|l|}
\hline Aug. & Sep. & Oct. & Nov. & Dec. & Jan. & Feb. & Mar. & Apr. & May. & Jun. & Jul. & Avr. & $\begin{array}{l}\text { Standered } \\
\text { Ddeviation }\end{array}$ \\
\hline 30 & 28.8 & 31.5 & 28 & 26.2 & 27.5 & 28.5 & 28.8 & 31.5 & 32.6 & 30.9 & 27.10 & 27.85 & 1.91 \\
\hline
\end{tabular}

The minimum water temperature was $26.2^{\circ} \mathrm{C}$ in December2012 and the maximum was reported $32.6^{\circ} \mathrm{C}$ in May 2012 at Barwani. The same observation were also reported by. Bhutaiani et al. (2016), Sharma et al
(2011) and Shraddha et al (2008) in Narmada river, while studying the hydrological parameters of Narmada river at Hoshangabad recorded water temperature between $27.6^{\circ} \mathrm{C}$ to $38.4^{\circ} \mathrm{C}$.

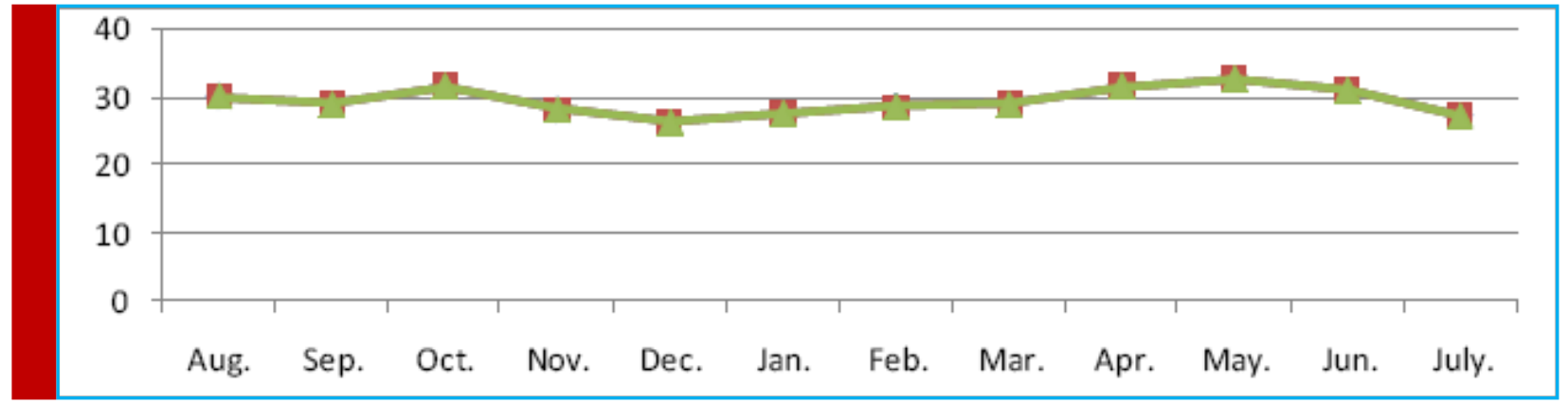

\section{PH RANGE}

$\mathrm{pH}$ is an important parameter which is important in evaluation the acid base balance of water. Natural waters generally have been found to range from 5.5 to
8.6 because of the presence of bicarbonates and carbonates of alkaline earth metals. Drinking water with a $\mathrm{pH}$ range from 6.5 to 8.3 has been necessary. During August 2011 to July 2012 the pH was fluctuated as follows.

Table 2. Monthly fluctuation in water $\mathrm{pH}$ of narmada river from August 2011 to July 2012 at barwani.

\begin{tabular}{|l|l|l|l|l|l|l|l|l|l|l|l|l|l|}
\hline aug. & Sep. & Oct. & Nov. & Dec. & Jan. & Feb. & Mar. & Apr. & May. & Jun. & Jul. & Avr. & $\begin{array}{l}\text { Standered } \\
\text { Ddeviation }\end{array}$ \\
\hline 8.2 & 8 & 8.4 & 8.5 & 8.7 & 8.26 & 8.4 & 7.8 & 9 & 8.8 & 8.5 & 7.9 & 8.37 & 0.34 \\
\hline
\end{tabular}

The minimum in March 2012 and the maximum in May 2012 at Barwani. Sharma et al (2011) observed pH fluctuation between 7.6 to 9.9 in Hoshangabad area of
Narmada river. Prasanna and Ranjan (2010) observed pH value between 7.5 to 8.5 in Dharma estuary. ency monitoring and therefore it has been an indication of effectiveness of filtration of water supplies (Hauser 2001). During August 2011 to July 2012 transparency was fluctuated as follows. 
Table 3. Monthly fluctuation in water transparency mg/l of narmada river from August 2011 to July 2012 at barwani.

\begin{tabular}{|l|l|l|l|l|l|l|l|l|l|l|l|l|l|}
\hline Aug. & Sep. & Oct. & Nov. & Dec. & Jan. & Feb. & Mar. & Apr. & May. & Jun. & Jul. & Avr. & $\begin{array}{l}\text { Standered } \\
\text { Ddeviation }\end{array}$ \\
\hline 22 & 21 & 37 & 33 & 39 & 53 & 48 & 39 & 27 & 31 & 29 & 20 & 33.16 & 10.56 \\
\hline
\end{tabular}

The minimum in July 2012 and maximum in January

by Prasanna and Panda (2010), Shraddha et al (2008) 2012 at Barwani. These observations were also supported

Tiwari, M and Dwivedi, A (2016) and Trivedi et al (2009).

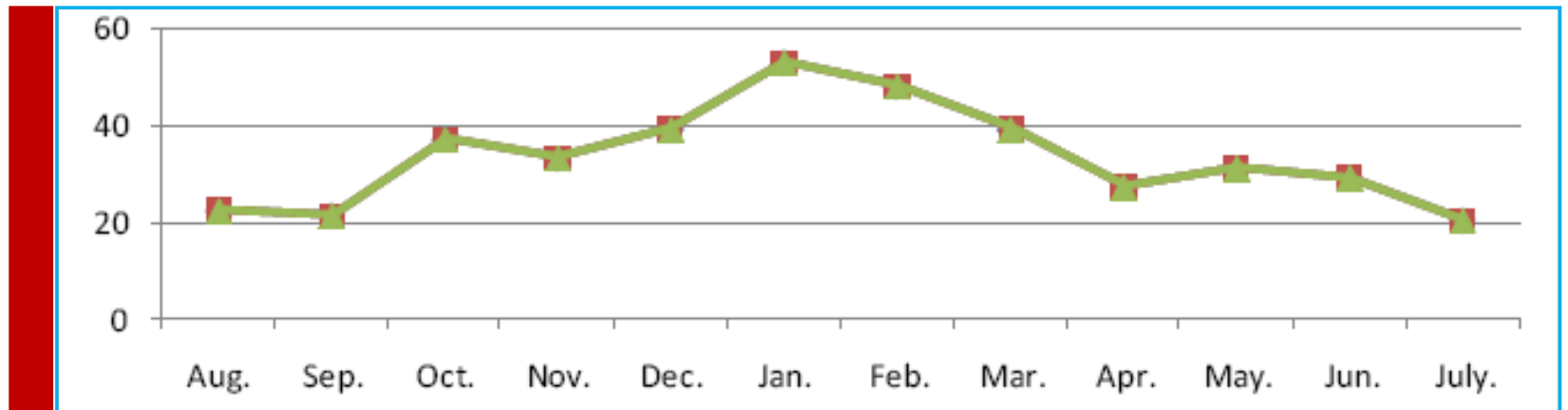

\section{TOTAL DISSOLVED SOLIDS}

The total solids are the total amount of chemical substance present in the water. The total dissolved solids and total suspended solids together make the total sol- ids in the water. The presence of solids in water vary greatly at different times and affect the density of water and there by the quality of aquatic environment. During August 2011 to July 2012 the value of total solids varied as follows.

Table 4. Monthly fluctuation in water total dissolved solid mg/l of narmada river from August 2011 to July 2012 at barwani.

\begin{tabular}{|l|l|l|l|l|l|l|l|l|l|l|l|l|l|}
\hline Aug. & Sep. & Oct. & Nov. & Dec. & Jan. & Feb. & Mar. & Apr. & May. & Jun. & Jul. & Avr. & $\begin{array}{l}\text { Standered } \\
\text { Ddeviation }\end{array}$ \\
\hline 160 & 145 & 136 & 124 & 109 & 180 & 185 & 156 & 135 & 152 & 159 & 119 & 146.6 & 22.31 \\
\hline
\end{tabular}

The minimum value was recorded in December 2011 and maximum in February 2012 at Barwani. Nduka et al (2008) also recorded total solids between 100 to 220

$\mathrm{mg} / \mathrm{l}$ in Niger delta of Nigeria and Khanna, D.R, and Rawat, S., Bhutiani, R., (2014).

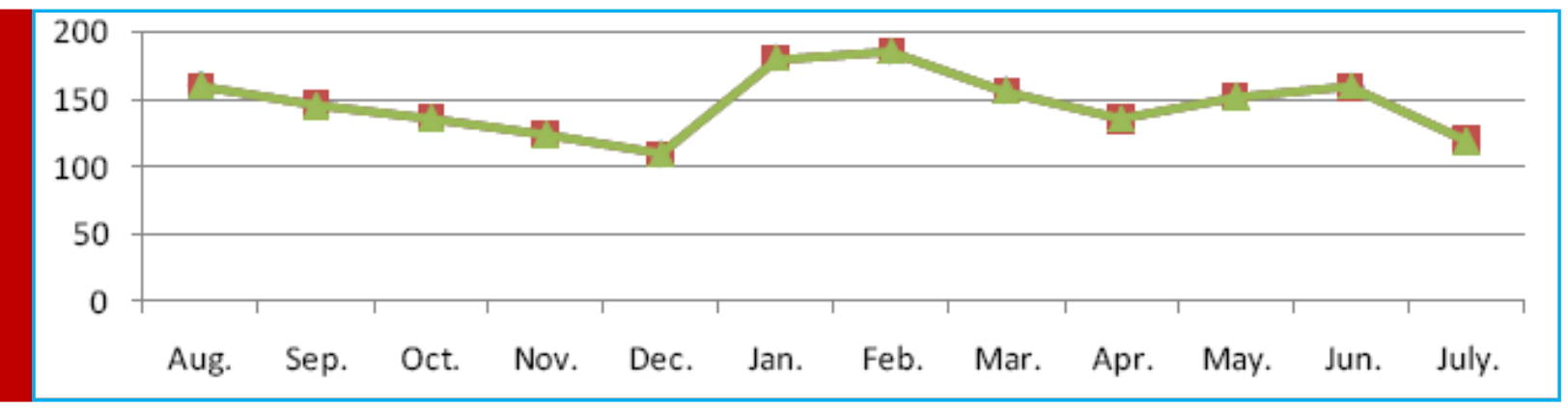

\section{ALKALINITY}

Alkalinity measures the buffering capacity of water and content of $\mathrm{CO} 2$ in its various forms are involved in this carbonate-bicarbonate carbonic acid buffering system. In the present study the value of Alkalinity varied as follows. 
Table 5. Monthly fluctuation in water alkalinity of narmada river from August 2011 to July 2012 at barwani.

\begin{tabular}{|l|l|l|l|l|l|l|l|l|l|l|l|l|l|}
\hline aug. & Sep. & Oct. & Nov. & Dec. & Jan. & Feb. & Mar. & Apr. & May. & Jun. & Jul. & Avr. & $\begin{array}{l}\text { Standered } \\
\text { Ddeviation }\end{array}$ \\
\hline 132 & 155 & 175 & 280 & 293 & 255 & 230 & 240 & 190 & 170 & 150 & 135 & 146.6 & 22.31 \\
\hline
\end{tabular}

The minimum value in Auguest 2011 and maximum in December 2011 atBarwani. Trivedi et al (2009) also observed the same value in Ganga river India.

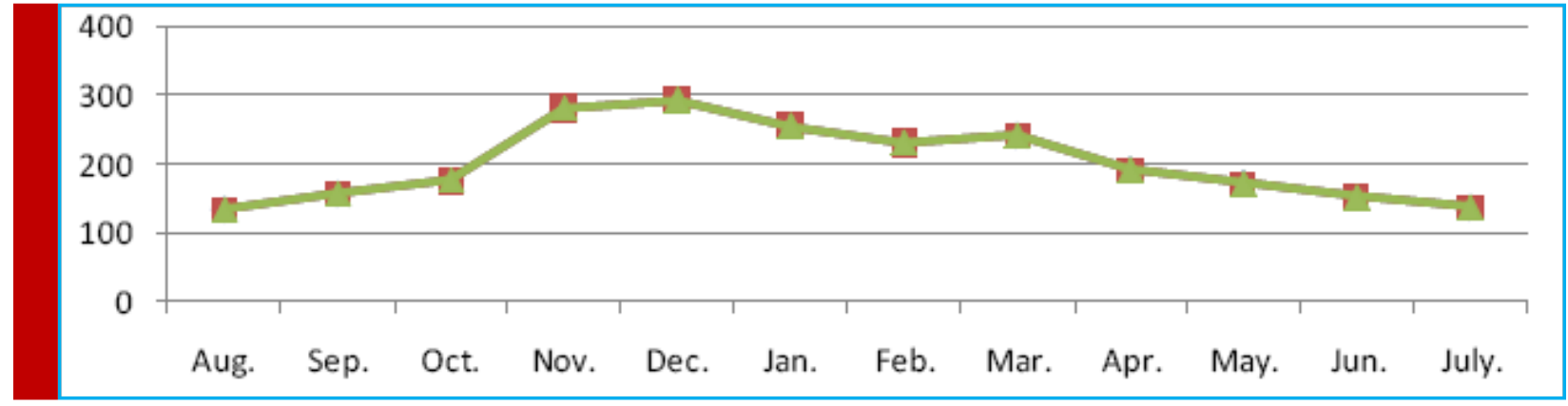

\section{BIOCHEMICAL OXYGEN DEMAND}

Biochemical oxygen demand is the amount of oxygen utilized by microorganism in stabilizing the organic matter in aerobic condition. DO measurement forms the basis of BOD analysis. It gives an indication of load of biodegradable organic material present in the water body. During the present study the BOD was fluctuated as follows.

\begin{tabular}{|c|c|c|c|c|c|c|c|c|c|c|c|c|c|}
\hline Aug. & Sep. & Oct. & Nov. & Dec. & Jan. & Feb. & Mar. & Apr. & May. & Jun. & Jul. & Avr. & $\begin{array}{l}\text { Standered } \\
\text { Ddeviation }\end{array}$ \\
\hline 4.9 & 5.9 & 5.7 & 4.6 & 4.3 & 3.9 & 3.5 & 5.6 & 6.6 & 4.4 & 5.2 & 5.4 & 5 & 0.86 \\
\hline
\end{tabular}

The minimum BOD was recorded February 2012 and maximum in April 2012 at Barwani. Same observations

were also recorded by Nnaji et al (2010) Katakwar, M (2014) and Mary et al (2008).

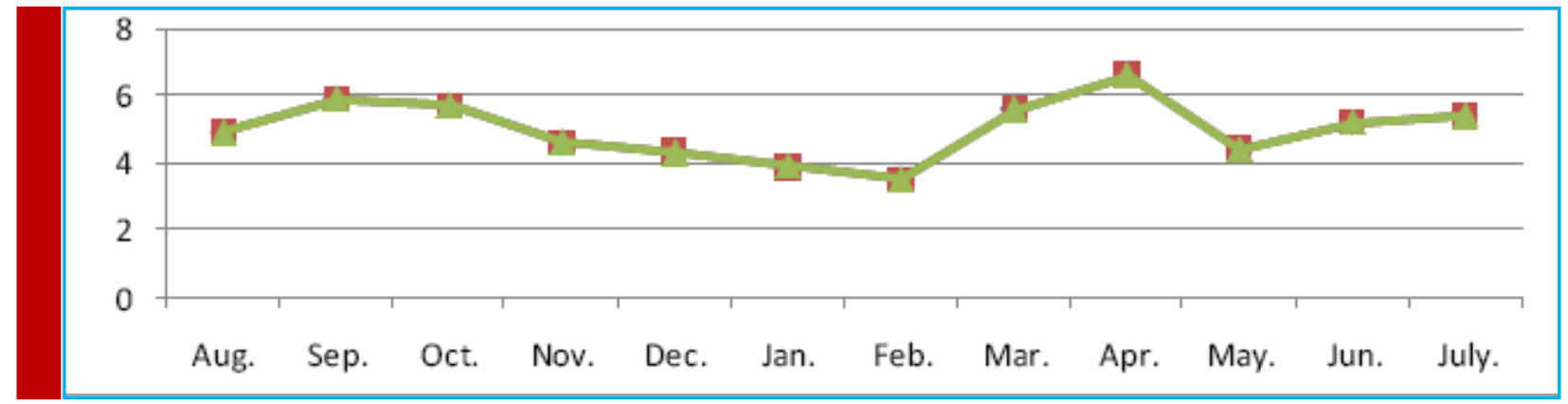

\section{REFERENCES}

Akhand., A and Srivastava, S. (2015): Seasonal biological water quality assessment of river Kshipra using benthic macro invertebrates Ujjain (M.P). Social Issues and environmental problems, Vol. (4), 342-350. ISSN-2350-0530.

Allan, J. \&t Flecker, A. (1993); Biodiversity conservation in running waters. Bioscience, Vol. 43, No. 1, (January 1993), pp. 32-43, ISSN 0006-3568.
APHA (2005): Standard method for examination of water and waste water, American Public Health Association Inc. New York $22^{\text {nd }} \mathrm{Ed}$.

Bhutaiani R, DB Kulkarni and D R Khanna (2016): Quality assessment of Ganga river at haridwar with references to various physico-chemical parameters. Biotechnology Society 9(1):17-24.

Gazetteer of Hoshangabad, (1979); Govt. of India, Madhya Pradesh. 
Govindan K, Kashinathan R, Desai BN. (1976) Macro benthic fauna in the polluted Thane creek \& Bombay Harbour, Indian J. Fish Assoc. 6:127-139.

Judy L.Meyer, David L,Strayer J and Bruce Wallace (2007) The contribution of headwater streams to biodiversity in river networks. J. Am. Water Res. Assoc. 43:86-103.

Katakwar, M (2014): Water quality and pollution status of Narmada river Anjan tributary in (M.P). Int. j. Curr. Res. Aca. Rev. 2(11) 93-98.

Kazanci N, Dugel M. (2000) Ordination and classification of macro-invertebrates and environmental data of stream in Turkey. Water Sci. Technol. 47: 7-8.

Khanna, D.R, and Rawat, S., Bhutiani, R., (2014). Recent trend in physico-chemical parameters of Song river at Nepali farm district Dehradun, Uttrakhand, J. Resea. Bioscience, Vol(2) 33-44 pp.

Khichi Yogesh (2017): Physico-chemical Evaluation of Water quality of Narmada river from Omkareshwar to Barwani, MP, India. J. of Natural and applied science. Issn: 2349-4077.

Kumar R, Chauhan A and Rawat. L (2017): Phyco-chemical analysis of surface and ground water in selected sites of Dehradun, Uttarakhand, India. J. Environ. Anal. Toxicol.10.4172/2161-0525.

Mary H. P. A., S. Jayasree, J. A. Johnson, B. J. Edith and I.H. Chittarasu (2010) Seasonal variations In physico-chemical parameters of water in coconut husk retting area, Parakkani, Tamil Nadu. Int. J. of Env. Sciences 1(6). 1056-1061.

Nduka J. K., 0. E. Orisakwe and L. 0. Ezenweke (2008) Some physico-chemical parameters of potable water supply in Warri, Niger Delta area of Nigeria. Scientific Research and Essay, 3 (11), pp. 547-551.

Nnaji J.C., A. Uzairu, G.F.S. Harrison and M.L. Balarabe (2010) Effect of Pollution on the Physico-chemical Parameters of Water and Sediments of River Galma, Zaria, Nigeria.Libyan Agriculture Research Center, 1 (2). pp 115-122.

Prasanna M. P. and P. C. Ranjan (2010) Physico-chemical properties of water collected from Dhamra estuary. Int. J. of env. Sciences 1(3) pp- 334-342.

Rao K.S, Das N.K and Pandya S.S (1985) Community structure of benthic macro-invertebrates and their utility as indicators of pollution in river Khan (Indore), India. Proc. Nat. Symp. Pure. And Appl. Limnology 32:114-119.

Richardson JS, Danehy RJ. (2007) Asynthesis of ecology of head water stream and their reparian zones in temperate forests.

Richter, B. Braun, D.; Mendelson, M. \&t Master L. (1997); Threats to imperilled freshwater fauna. Conservation Biology, Vol.11, No. 5, (October 1997), pp.1081-1093, ISSN08888892.

Sharma K. K., S. Chowdhary and A. Sharma (2010) Malaco fauna diversity of river Chenab fed stream (Gho-Manhasan), The Bioscan 6(2) pp 267-269.

Sharma S and Barkale S (2016): The species richness and abundance of macro-invertebrates in Bilawali Talab Indore (M.P.), India. IJFAS 4 (5): 311-315, ISSN: 2347-5129.

Sharma S, Joshi V, Kurde S, Sighavi M. (2007) Bio-diversity of benthic macro-invertebrates and fish species communities of Krishnapura lake, Indore, M.P. Aqua Bio. 22(1):1-4.

Sharma S., V. Rakesh, D. Savita and J. Praveen (2011). Evaluation of water quality of Narmada river with reference to physico-chemical parameters at Hoshangabad city, MP, India. Res. J. Chem. Sci. 1(3) pp 40-48.

Shraddha S., D. Savita, J. Praveen, K. W. Shah, R. Vishwakarma (2008) Statistical evaluation of hydrological parameters of Narmada river water at Hoshangabad city, India. Environ Monit Assess.143: 195-202.

Strayer D, Dudgeon D. (2010); Freshwater biodiversity conservation: recent progress and future challenges. Journal of the North American Benthological Society. 29:344-358.

Sunny A, Vattakeril, Diwan AP. (1991) Community structure of benthic macro-invertebrates \&t their utility as indicators of pollution in river Kshipra, India. J. Pollution Research. 10:1-11.

Thorne RS, William WP. (1997) The response of benthic macroinvertebrates to pollution in developing countries. A multimetric system of bioassessment. Freshwater Biol. 37: 671-686.

Tiwari, M and Dwivedi, A(2016): Suitability analysis of water in an urban tropical lake using seasonal water quality index. Biology and Medicine Vol. (2) 83-87.

Trivedi P., A. Bajpai and S. Thareja (2009) Evaluation of water quality: Physico-chemical characteristics of Ganga river at Kanpur Ind J of Env. Biology Vol 32 45-57. 